\title{
15. AUTHIGENIC CARBONATE NODULES IN THE NANKAI TROUGH, SITE 5831
}

\author{
C. L. Stein, Earth Sciences, Sandia National Laboratories \\ and \\ A. J. Smith, Department of Geology, Bedford College, University of London²
}

\begin{abstract}
Crystalline aggregates composed of calcium carbonate were recovered in the uppermost $50 \mathrm{~m}$ of Nankai Trough sediments during DSDP Leg 87A. These aggregates decomposed with time to masses of sandy calcite as determined by $\mathrm{X}$-ray diffraction analysis. Petrographic and scanning electron microscopy revealed textures suggestive of a precursor phrase prior to calcite, and this precursor has been tentatively identified as the mineral ikaite, $\mathrm{CaCO}_{3} \cdot 6 \mathrm{H}_{2} \mathrm{O}$. Stable isotope data suggest a large component of terrigenous organic matter as the carbon source, consistent with the appearance of these aggregates in highly reducing pyritic sediments containing abundant plant remains. We propose that these nodules formed in euxinic basins on the upper part of the Trough slope under normal seafloor conditions of pressure and temperature. Calculated temperatures of formation of this phase are not unusually low. The specimens from Site 583 are the first reported occurrences of ikaite in active margin sediments.
\end{abstract}

\section{INTRODUCTION}

Highly calcareous layers, ranging in thickness from a few millimeters to centimeters, were encountered at DSDP Site 583 in sediments from the Nankai Trough, during Leg 87A. Site 583 is located in the lowermost structural terrace on the western (landward) side of the Nankai Trough, approximately $15 \mathrm{~km}$ east of Site 298. The sediments, apparently free of biogenic carbonate remains, contained massive, white to yellowish brown, coarsely crystalline aggregates of calcium carbonate. Some of these aggregates (most notably, those from Holes 583, $583 \mathrm{~A}$, and $583 \mathrm{C}$ ) occurred in the form of large (up to $5 \mathrm{~cm}$ in length) euhedral crystals in which calcite twinning and scalenohedral terminations were common (Figure 1).

A few of these large nodules were removed from the cores immediately after they were split in the shipboard core lab; pieces of the crystalline carbonates were impregnated with epoxy and cut into thin sections. Microscopic examination showed the samples to consist primarily of relatively large (10-50 $\mu \mathrm{m})$, usually rhombohedral, and distinctly zoned crystals embedded in a porous groundmass composed of much finer-grained acicular calcareous material (see Figs. 2 and 3). Simultaneously, by X-ray diffraction of portions of these samples, we identified the mineral composition as a mixture of calcite and aragonite.

Significantly, even as the freshly split cores were being described, the crystals appeared to melt, changing luster and color to an opaque milky yellow in a matter of minutes. The crystalline form was gradually lost as they collapsed into a mass of minute crystals. Approxi-

\footnotetext{
${ }^{1}$ Kagami, H., Karig, D, E., Coulbourn, w. T., et al., Init, Repts, DSDP, 87: Washington (U.S. Govt. Printing Office).

Addresses: (Stein) Earth Sciences, Division 6331, Sandia National Laboratories, Albuquerque, New Mexico 87185; (Smith) Department of Geology, Bedford College, University of London, London NW1 4N5, England.
}

mately 6 months later, when we re-examined the DSDP archive cores containing these nodules, the crystals had disappeared entirely, leaving only their molds and friable masses of pale yellow sand-sized fragments.

Subsequent consideration of this phenomenon suggests that the large aggregates seen on board the Challenger were crystals of the mineral ikaite (Pauly, 1963), a low-temperature hydrated calcium carbonate $\left(\mathrm{CaCO}_{3}\right.$. $6 \mathrm{H}_{2} \mathrm{O}$ ) that was discovered in the Ika Fjord, Greenland. We present here our analyses of the samples from the Nankai Trough as well as an explanation for the presence of this mineral in these sediments.

\section{CARBONATE AGGREGATE MINERALOGY}

$\mathrm{X}$-ray diffraction analyses of the carbonate aggregates were performed on board ship within $24 \mathrm{hr}$. of core recovery from Site 583 . Small samples were briefly ground in a mortar and mounted on glass slides before insertion in a Rigaku Miniflex X-ray diffractometer. As the crystalline aggregates were very soft and poorly consolidated, very little grinding was required to produce a powder that was sufficiently fine for a smear mount. The samples were analyzed at a scan rate of $1^{\circ} 2 \theta / \mathrm{min} ., 1000$ counts/s, with $\mathrm{Cu} \mathrm{K} \alpha$ radiation. These were the first $\mathrm{X}$-ray diffractograms we obtained from these crystals, and, although these records suffice for the purpose of major mineral identification, the shipboard X-ray diffraction equipment does not produce high-quality traces. The resultant patterns were identified as almost entirely a mixture of calcite and aragonite, based on the presence of their major peaks at 29.36 and $26.18^{\circ} 2 \theta$, respectively. The positions of the major aragonite peaks seen in these diffraction patterns correspond closely with those of the ASTM standard aragonite file; however, the peak intensities do not correlate well. One cause of this lack of correlation may be a preferred orientation in the smear mount; another possible cause may be that the mineral is something other than aragonite per se (e.g., a hydrat- 


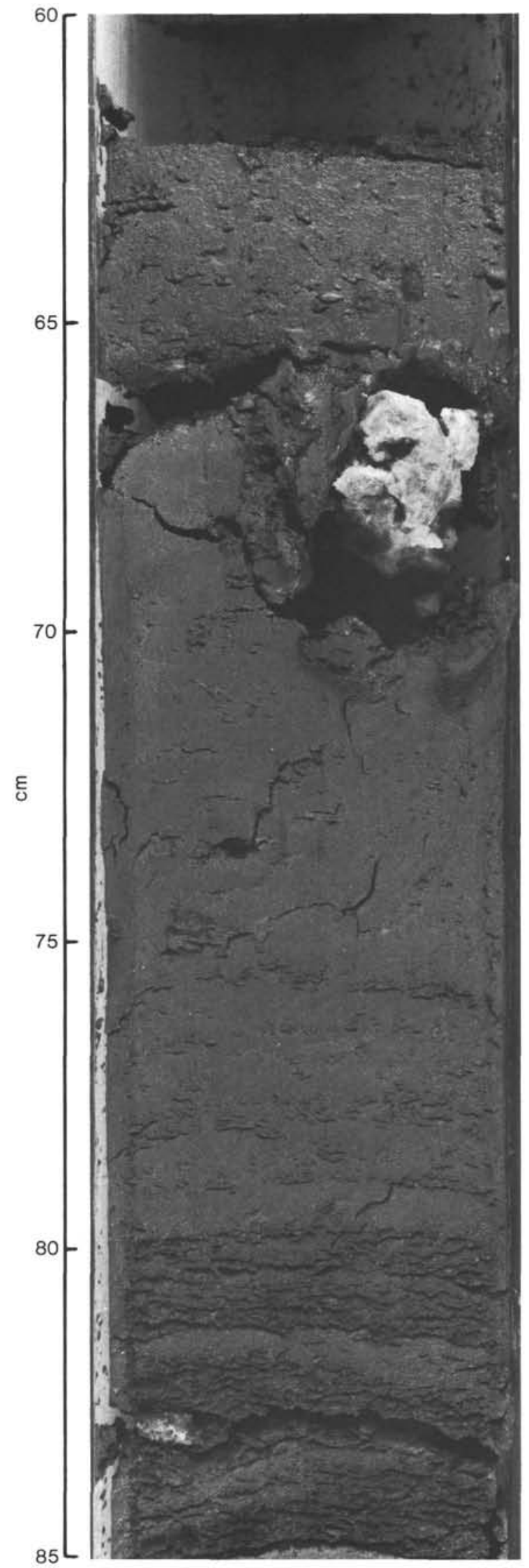

Figure 1. Appearance of carbonate nodules on freshly split core from $583 \mathrm{~A}-3-3,60-85 \mathrm{~cm}$.

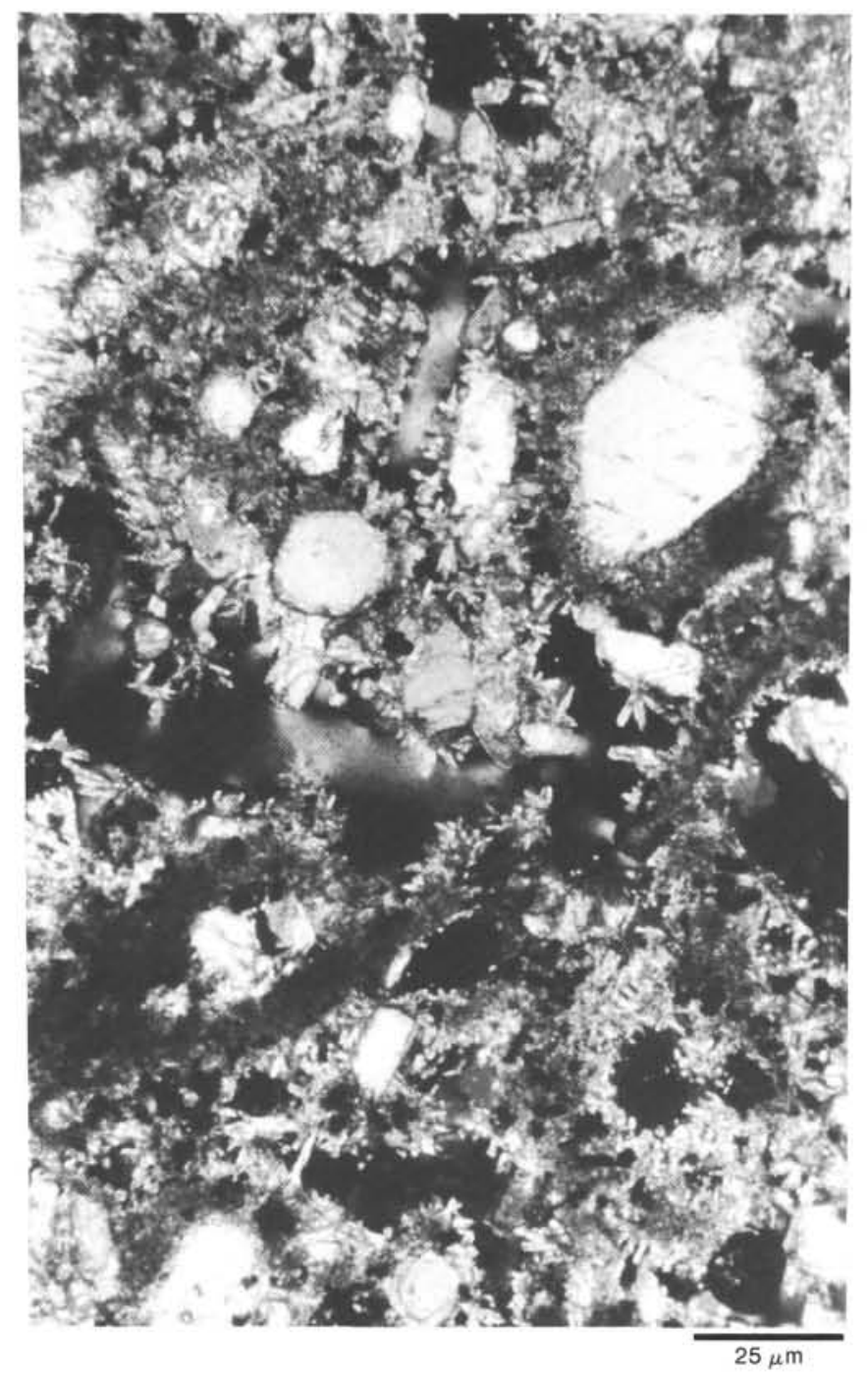

Figure 2. Thin-section photomicrograph showing carbonate rhombs in acicular matrix. Section 583C-2-2.

ed calcium carbonate form with a structure that very closely resembles aragonite).

\section{OPTICAL PETROGRAPHY}

In thin section, these nodules are composed of large (on the average, 10-50 $\mu \mathrm{m}$ ), highly birefringent, rhombic crystals in an acicular groundmass. Frequently, the rhomb-shaped crystals grow in voids lined with the needlelike crystals. Moreover, the voids appear to display a preferred orientation with respect to the rhombs, suggesting in situ growth of the entire mass (Fig. 4). The $\mathrm{X}$-ray diffraction data, together with the morphology of the individual crystals that compose these aggregates as seen in thin section, lead us to speculate that the acicular groundmass is composed of what we have tentatively identified as aragonite needles in which are embedded the larger calcite crystals.

Many of the larger rhombs clearly gave the appearance of being zoned in these thin sections (Fig. 5). However, when fragments of the decomposed nodules were examined much later by cathodoluminescence and the 


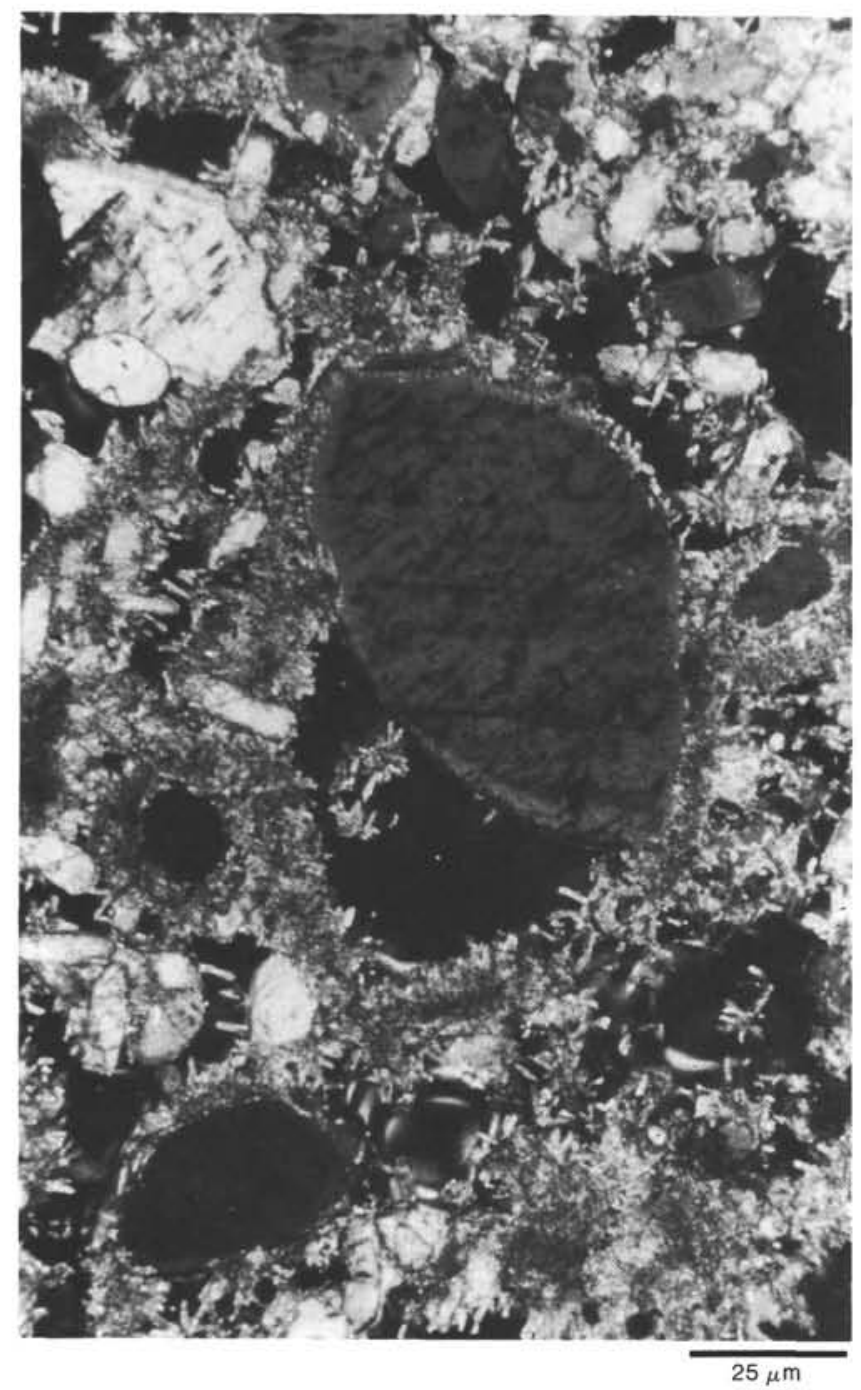

Figure 3. Thin-section photomicrograph showing carbonate rhombs in acicular matrix. Section 583C-2-2.

electron microprobe, no well-defined compositional zones were observed.

\section{MICROPROBE ANALYSIS}

Individual carbonate fragments were embedded in coldmount epoxy for analysis by electron microprobe. The instrument used was a Cameca MBX electron microprobe X-ray analyzer with the Tracor-Northern automation package, operated under the Sandia-TASK program. Probe scans were run at $15 \mathrm{kV}, 11 \mathrm{nA}$, count time = $33 \mathrm{~s}$, with $1 \%$ standard deviation. Standard materials were run, as follows, with Bence-Albee correction BA-78 (Chambers, 1979): $\mathrm{Ca}$, wollastonite; $\mathrm{Mg}$, synthetic $\mathrm{MgO}$; $\mathrm{Fe}$, hematite (Elba); Mn, spessartine; and $\mathrm{Sr}, \mathrm{SrTiO}_{3}$.

Of these elements, only $\mathrm{Ca}$ and $\mathrm{Mg}$ were detected in significant quantities. The $\mathrm{Mg}$ content varied between less than 0.1 and $1.0 \mathrm{wt} . \%$; these aggregates are virtually pure $\mathrm{CaCO}_{3}$. The distribution of $\mathrm{Mg}$ is shown in Figure 6. The outer zone of the crystals shown in this photograph contain on the order of $1 \mathrm{wt} \% \mathrm{Mg}$, decreasing to approximately $0.1 \mathrm{wt} . \%$ in the center. This pattern could reflect either the original chemical zona- tion or $\mathrm{Mg}-\mathrm{Ca}$ exchange by diffusion from surrounding interstitial water that occurred some time after core recovery and storage. In any case, the $\mathrm{Mg}^{2+}$ concentration is insufficiently high to show distinct zonation when subjected to cathodoluminescence. In addition, at the time at which these crystal fragments were analyzed by the microprobe, they were observed to contain approximately 0.5 molecule of water (as determined by difference).

As a means of verifying the presence of excess water in the $\mathrm{CaCO}_{3}$ crystal structure, we decided to $\mathrm{x}$-ray one of these samples again on a high-resolution diffractometer and compare the results to the d-values and lattice parameters of standard calcite.

\section{HIGH-RESOLUTION X-RAY DIFFRACTION}

A smear slide was made of the crystalline residue from one of the Site 583 cores $(583 \mathrm{C}-2-1,71-72 \mathrm{~cm}$ ) approximately $1 \mathrm{yr}$. after the core was recovered. High-resolution X-ray diffraction analyses were done using a Siemens D-500 automated powder diffractometer and $\mathrm{Cu}$ $\mathrm{K} \alpha$ radiation at $40 \mathrm{kV}$ and $30 \mathrm{~mA}$. This diffractometer is linked to a DEC PDP11/34 RT11; SIEMAC, the program in use for X-ray identification, was used to scan the region between 20 and $96^{\circ} 2 \theta$ in $0.02^{\circ} 2 \theta$ steps. A least-squares program, developed by $\mathrm{D}$. Appleman (USGS), was used to calculate the lattice parameters using the following (for a hexagonal primitive cell):

$$
\begin{aligned}
\text { a and b: } 4.99000 \quad \alpha, \beta & =90^{\circ} \\
\text { c: } 17.00200, \quad \gamma & =120^{\circ} .
\end{aligned}
$$

Using these values for a standard calcite unit cell, we measured the lattice parameters on Sample 583C-2-1, $71-72 \mathrm{~cm}$ :

$$
\begin{array}{r}
\text { a and b: } 4.96929 ; \text { Std. error }=4.09 \times 10^{-3} \\
\text { c: } 16.92956 ; \text { Std. error }=3.60 \times 10^{-2} .
\end{array}
$$

In an attempt to rule out any possibility that the basic calcite structure of these crystals was distorted because of the presence of residual water molecules, we heated the slide to $75^{\circ} \mathrm{C}$ for $8 \mathrm{hr}$. and then $\mathrm{x}$-rayed again. Using the same $h \mathrm{kl}$ and standard calcite unit cell parameters, the values for the heated sample were:

$$
\begin{array}{r}
\text { a and b: } 4.97419 ; \text { Std. error }=4.28 \times 10^{-3} \\
\text { c: } 16.96540 ; \text { Std. error }=5.56 \times 10^{-2}
\end{array}
$$

In summary, there seems to be little doubt that the mineralogy of this specimen is calcite. A comparison of the X-ray data on which this conclusion is based is presented in Table 1.

\section{STABLE ISOTOPE ANALYSIS}

The $\delta^{13} \mathrm{C}$ and $\delta^{18} \mathrm{O}$ (relative to the PDB standard) values of selected samples (Table 2) were obtained using a Varian-Mat triple collector mass spectrometer and the standard analytical procedure (e.g., digestion of sample material by $100 \%$ phosphoric acid). The $\delta^{13} \mathrm{C}$ values are all considerably lighter than expected for a marine carbonate; this anomaly and its implications for diagene- 


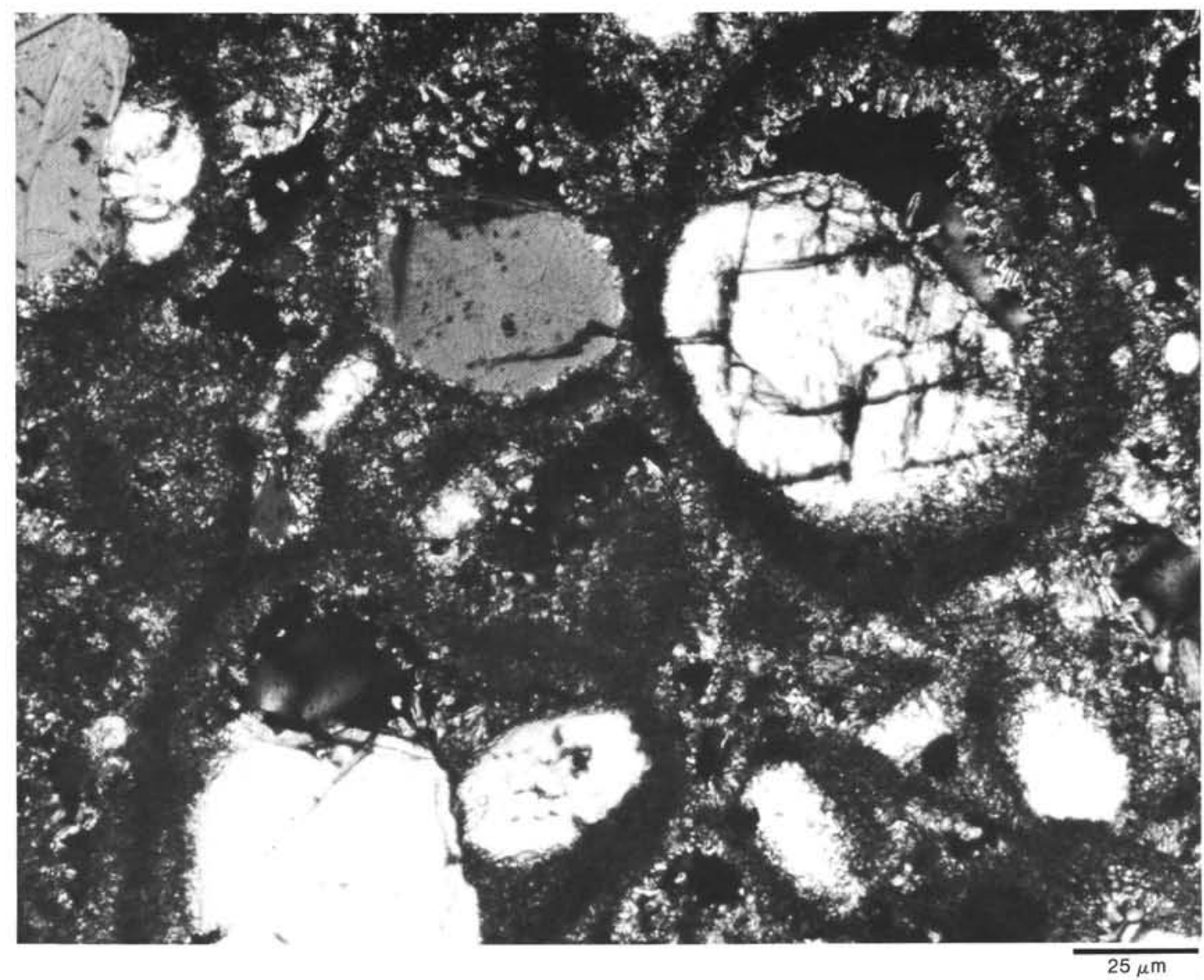

Figure 4. Geopetal(?) orientation of abundant voids in a thin-section photomicrograph. Section 583E-H1-2.

sis involving a terrestrial organic carbon source are discussed below.

Paleotemperatures for the formation of these nodules are calculated according to the equation of Epstein (in press) and are shown in Table 2. These temperatures, ranging from approximately 4.6 to $7.7^{\circ} \mathrm{C}$, are within the range of normal seafloor conditions.

\section{SCANNING ELECTRON MICROSCOPY}

Finally, several fragments of the carbonate nodules were examined with a Hitachi S-500 scanning electron microscope, at an operating voltage of $25 \mathrm{kV}$. The photographs seen in Figures 7 and 8 display a variety of crystal forms. The gross morphology (e.g., Fig. 7) very closely resembles that of the "pseudogaylussite" first described by Trechmann (1901), the "thinolite" crystals in Dana (1884), and similar forms described by Boggs (1972), Kemper and Schmitz $(1975 ; 1981)$, and Kaplan (1963).

At successively higher orders of magnification, however, these fragments appear to be composed of, or covered with, much smaller rhombohedral crystals (Fig. 8). There is virtually no evidence, as seen in the scanning electron micrographs, of the acicular masses seen in the thin sections that were made on board ship immediately after core recovery (Fig. 2, for example). The implication here is that, once the original nodules decomposed (or perhaps "melted" would be more accurate), the al- teration of $\mathrm{CaCO}_{3}$ was rapid and in situ, and took the form seen in Figure 8.

\section{DISCUSSION}

These nodules, composed of an apparently ephemeral calcium carbonate phase, changed rapidly in appearance, mineralogy, and structure from the time the original cores were first opened on board the Glomar Challenger. Based primarily on the admittedly circumstantial evidence consisting of the rapidity of alteration of these masses, their texture as seen in thin section, and the similarity to other reported occurrences of poorly defined calcium carbonate phases, we propose that these crystalline aggregates were originally composed of the mineral ikaite, $\mathrm{CaCO}_{3} \cdot 6 \mathrm{H}_{2} \mathrm{O}$. Furthermore, X-ray diffraction evidence, both aboard ship and after approximately $1 \mathrm{yr}$. in core storage, indicates a transformation from a highly hydrated phase to a mixture of calcite and aragonite to well-crystallized calcite according to the following scheme:

$\begin{array}{cc}\text { Low temperature } & \text { High temperature } \\ \text { High P } & \text { Low P }\end{array}$

$\begin{array}{ll}\text { ikaite } & \rightarrow \text { calcite }+ \text { aragonite } \rightarrow \text { calcite } \\ \mathrm{CaCO}_{3} \cdot 6 \mathrm{H}_{2} \mathrm{O} & \rightarrow \mathrm{CaCO}_{3}+\mathrm{CaCO}_{3} \rightarrow \mathrm{CaCO}_{3} \\ \left(+\mathrm{CH}_{4} \cdot 6 \mathrm{H}_{2} \mathrm{O} ?\right) & \end{array}$ 


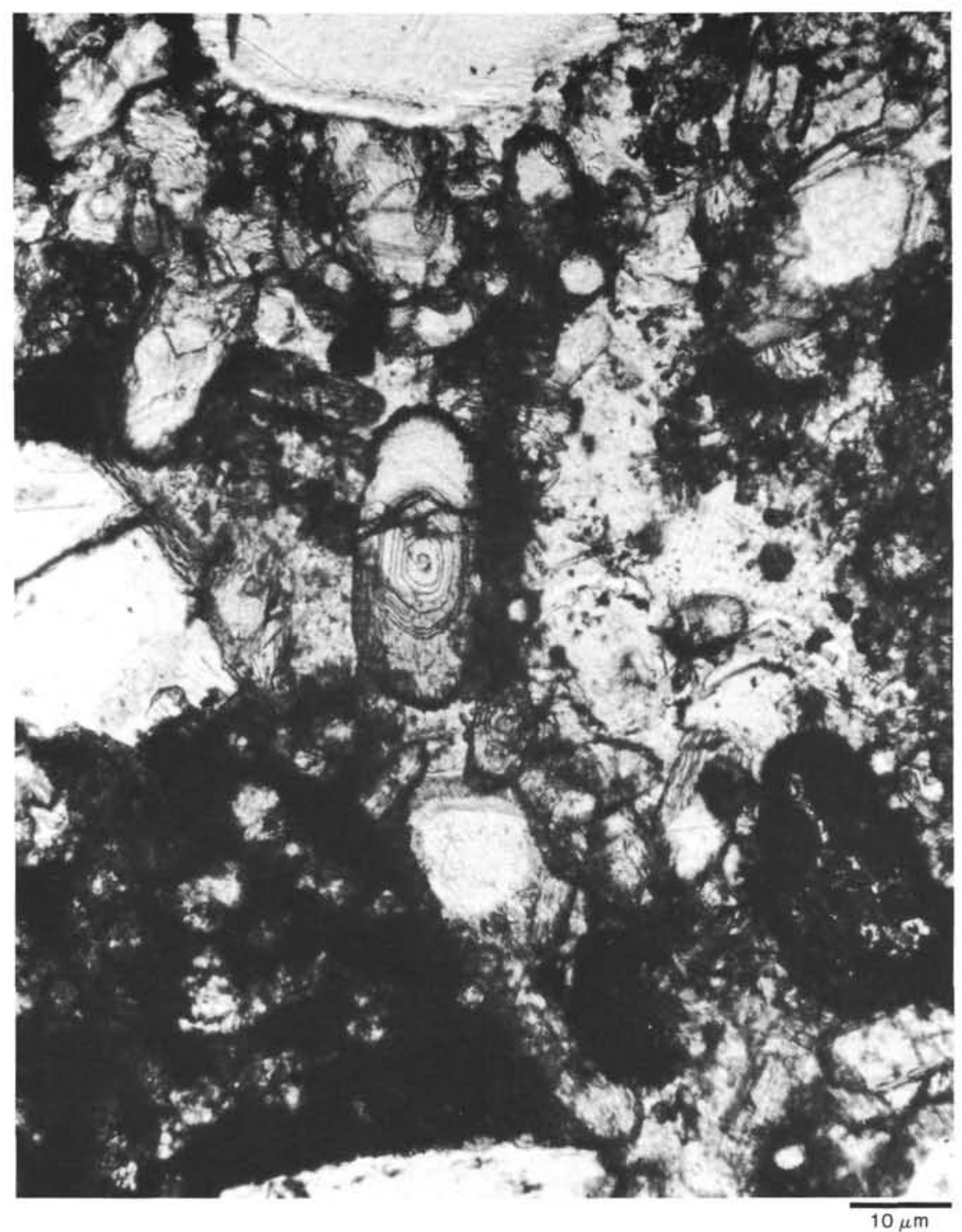

Figure 5. Thin-section photomicrograph showing distinctive concentric zoning in rhombic carbonate. Zonation was not, however, related to chemical composition. Section 583E-H1-2.

No other carbonate phases appear in this reaction; the resultant calcite is exceptionally pure, containing less than $1 \% \mathrm{MgO}$ and no detectable quantities of strontium, iron, or manganese. Unlike the carbonates from DSDP Sites 438 and 439 in the Japan Trench (Legs 56 and 57; Matsumoto and Iijima, 1980), we found no evidence of either dolomite or ankerite in the aggregates described in this report.

The shipboard interstitial water profiles (Figs. 9-11) for calcium, manganese, and alkalinity are also consistent with an environment conducive to authigenic carbonate formation. At Site 583 these aggregates are exclusively associated with sandy pyritic sediments that contain abundant plant remains. The high sediment accumulation rates in the upper part of this section (225$315 \mathrm{~m} / \mathrm{Ma}$; site chapter, Site 583 , this volume) undoubtedly contributed to the deposition of organic material and the subsequent formation of localized highly reducing environments. The most likely explanation for this is a coupled reaction in which dissolved sulfate in interstitial waters is reduced in the presence of organic carbon from terrestrial plant material; the sulfide thus formed is precipitated as pyrite and the oxidized carbon as calcium carbonate.

The unusually light $\delta^{13} \mathrm{C}$ values (Table 2) also support a significant contribution of organic carbon from terrestrial sources. The trends shown in the interstitial water profiles at Site 583 are quite similar to those from Sites 438 and 440 in the Japan Trench (Moore and Gieskes, 1980); $\mathrm{Ca}^{2+}$ increases linearly with depth, whereas both $\mathrm{Mg}^{2+}$ and alkalinity increase in the uppermost $50 \mathrm{~m}$, then decrease steadily.

Two possibilities are suggested by the paleotemperatures calculated from the oxygen isotope data. One is that these temperatures (Table 2) are accurate for bottom-water conditions at the time of carbonate precipitation; perhaps, at this water depth, the pressure is sufficiently high for ikaite formation without suggesting ex- 

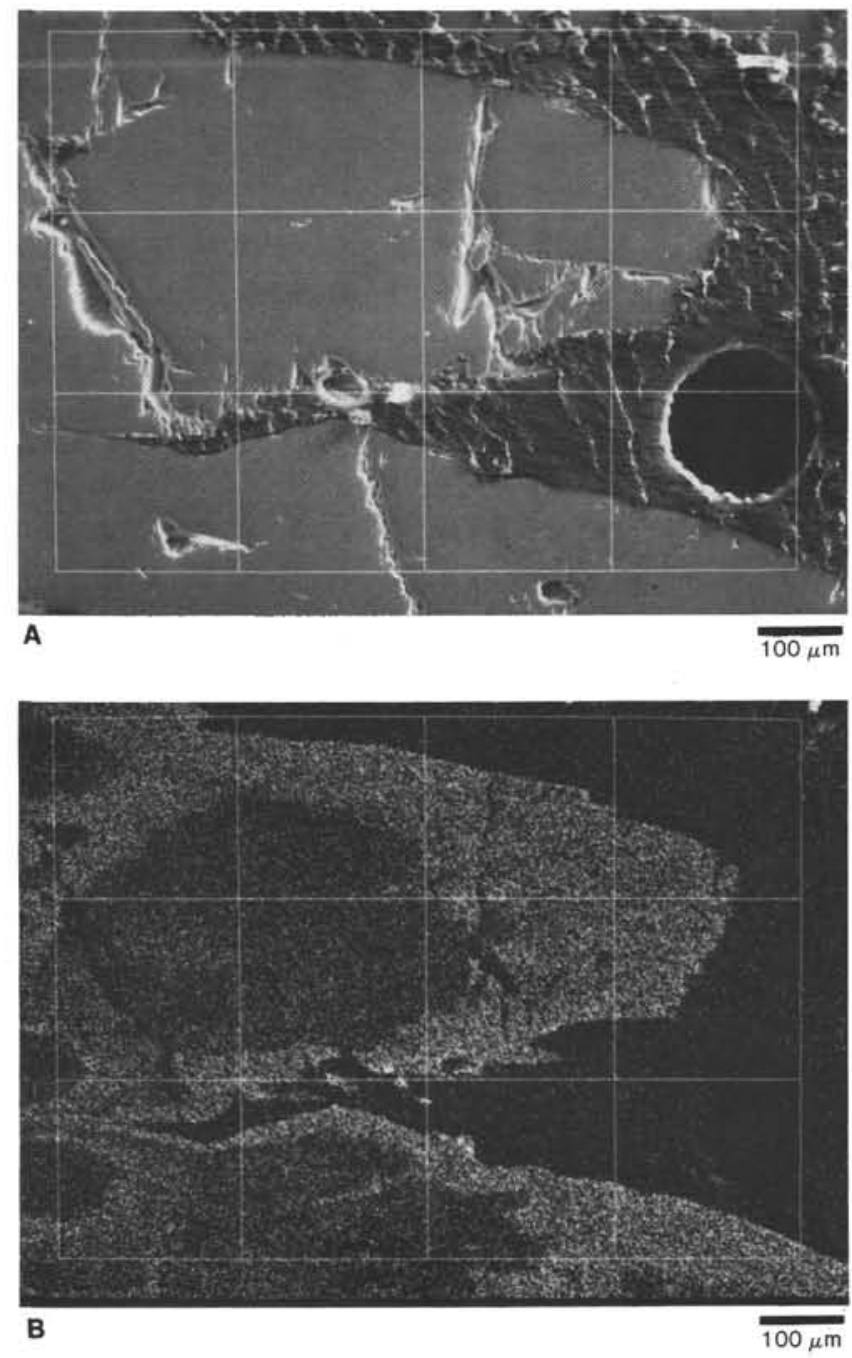

Figure 6. Microprobe photographs showing (A) carbonate fragments embedded in epoxy and (B) distribution of $\mathrm{Mg}^{2+}$, with a maximum of $1 \%$ at the outer edges, probably resulting from postrecovery diffusion of interstitial water.

ceptionally low temperatures. A second possibility is that the ikaite crystals were initially formed at a time when bottom-water temperatures in the Nankai Trough were much lower and that they subsequently reequilibrated with warmer water some time after deposition.

We can only speculate on the presence of clathrates $\left(\mathrm{CH}_{4} \cdot 6 \mathrm{H}_{2} \mathrm{O}\right)$ within the calcareous aggregates. Organic matter is abundantly present in these sediments, so possibly sufficient methane was generated before sulfate reduction to coprecipitate with $\mathrm{CaCO}_{3} \cdot 6 \mathrm{H}_{2} \mathrm{O}$. Although the pressure-temperature conditions at Site 583 were more than adequate for the formation of clathrates (Katz, 1971), we saw no direct evidence, other than the nodules, that a gas-ice mixture had been present.

Crystals similar to those seen on Leg 87A were recovered by the Meteor expedition to the Antarctic Ocean in 1980 (Suess et al., 1982). Apparently these samples also decomposed rapidly and were altered to calcite in the ship's laboratory; the identification made by the shipboard scientists was ikaite.

\section{CONCLUSIONS}

We speculate that the foregoing conditions-i.e., high organic carbon input, high sedimentation rates, high alkalinity, and reducing conditions-must have been extremely favorable for the precipitation of a calcium carbonate phase, probably ikaite $\left(\mathrm{CaCO}_{3} \cdot 6 \mathrm{H}_{2} \mathrm{O}\right)$ and possibly intergrown with clathrates $\left(\mathrm{CH}_{4} \cdot 6 \mathrm{H}_{2} \mathrm{O}\right)$. This conclusion is largely based upon the physical appearance of these crystals in freshly split cores, their subsequent disintegration, and their texture as observed in thin sections made immediately after core recovery. The similarity of the morphologies seen in the electron micrographs (Figs. 7, 8) also lend credence to this supposition, because these pseudomorphs (which are now composed purely of calcite) strongly resemble those of ikaite as discussed elsewhere in the literature. Temperatures of equilibration, as calculated from oxygen isotopic compositions, do not suggest unusually extreme climatic conditions. On the contrary, although these crystalline ag- 
Table 1. X-ray diffraction data of standard calcite, calcareous nodule from Sample 583C-2-1, 71-72 cm, and the same sample after heating.

\begin{tabular}{|c|c|c|c|c|c|c|c|c|}
\hline \multicolumn{3}{|c|}{ ASTM standard: calcite } & \multicolumn{3}{|c|}{ Sample $583 \mathrm{C}-2-1,71-72 \mathrm{~cm}$ (unheated) } & \multicolumn{3}{|c|}{ Sample $583 C-2-1,71-72 \mathrm{~cm}$ (heated) } \\
\hline $\begin{array}{l}\text { Peak position } \\
\text { (degrees } 2 \theta \text { ) }\end{array}$ & d-spacing & Intensity & $\begin{array}{l}\text { Peak position } \\
\text { (degrees } 2 \theta)\end{array}$ & d-spacing & Intensity & $\begin{array}{l}\text { Peak position } \\
\text { (degrees } 2 \theta \text { ) }\end{array}$ & d-spacing & Intensity \\
\hline 1. 23.02 & 3.861 & 12 & 1. 23.292 & 3.8189 & 9.2 & 1. 23.262 & 3.8237 & 5.6 \\
\hline 2. 29.36 & 3.040 & 100 & 2. 29.676 & 3.0102 & 100.0 & 2. 29.614 & 3.0165 & 100.0 \\
\hline 3. 31.37 & 2.849 & 3 & 3. 31.725 & 2.8204 & 3.6 & 3. 36.211 & 2.4806 & 8.1 \\
\hline 4. 35.98 & 2.494 & 15 & 4. 36.261 & 2.4773 & 6.8 & 4. 39.627 & 2.2743 & 9.7 \\
\hline 5. 39.44 & 2.283 & 20 & 5. 39.684 & 2.2711 & 14.7 & 5. 43.368 & 2.0856 & 6.5 \\
\hline 6. 43.11 & 2.096 & 20 & 6. 43.436 & 2.0833 & 8.4 & 6. 47.340 & 1.9202 & 3.9 \\
\hline 7. 47.13 & 1.927 & 5 & 7. 47.406 & 1.9177 & 3.5 & 7. 47.705 & 1.9063 & 11.5 \\
\hline 8. 47.51 & 1.912 & 15 & 8. 47.745 & 1.9048 & 16.6 & 8. 48.717 & 1.8691 & 12.1 \\
\hline 9. 48.48 & 1.876 & 15 & 9. 48.770 & 1.8672 & 16.4 & 9. 56.745 & 1.6222 & 2.6 \\
\hline 10. 56.55 & 1.626 & 4 & 10. 56.828 & 1.6201 & 2.2 & 10. 57.592 & 1.6004 & 6.1 \\
\hline 11. 57.36 & 1.605 & 8 & 11. 57.640 & 1.5992 & 17.9 & 11. 58.217 & 1.5847 & 3.1 \\
\hline 12. 58.06 & 1.587 & 2 & 12. 58.312 & 1.5823 & 3.6 & 12. 60.863 & 1.5220 & 2.8 \\
\hline 13. 60.70 & 1.524 & 5 & 13. 60.909 & 1.5209 & 3.5 & 13. 64.875 & 1.4372 & 28.3 \\
\hline 14. 61.01 & 1.517 & 4 & 14. 61.255 & 1.5132 & 3.6 & 14. 65.763 & 1.4199 & 2.0 \\
\hline 15. 61.32 & 1.511 & 3 & 15. 64.894 & 1.4368 & 20.5 & 15. 73.072 & 1.2949 & 2.1 \\
\hline 16. 63.07 & 1.473 & 2 & 16. 65.048 & 1.4338 & 5.3 & 16. 83.945 & 1.1527 & 15.0 \\
\hline 17. 64.63 & 1.441 & 5 & 17. 65.819 & 1.4189 & 3.4 & 17. 95.158 & 1.0443 & 4.4 \\
\hline
\end{tabular}

Note: ASTM $=$ American Society for Testing and Materials.

Table 2. Stable isotope data, Site 583.

\begin{tabular}{lcccc}
\hline $\begin{array}{c}\text { Hole-Core-Section } \\
\text { (interval in cm) }\end{array}$ & $\begin{array}{c}\text { Sub-bottom } \\
\text { depth } \\
(\mathrm{m})\end{array}$ & ${ }^{13} \mathrm{C}$ & $\delta^{18} \mathrm{O}$ & $\begin{array}{c}\text { Temperature } \\
\left({ }^{\circ} \mathrm{C}\right)\end{array}$ \\
\hline $583 \mathrm{~A}-2-3,143-145$ & 8.4 & -28.88 & +2.93 & 5.21 \\
$583 \mathrm{~A}-3-1,32-33$ & 9.3 & -25.26 & +2.77 & 5.77 \\
$583-2-4,44-45$ & 10.4 & -30.41 & +3.12 & 4.57 \\
$583 \mathrm{~A}-3-3,125-128$ & 12.2 & -26.18 & $+2.677^{\mathrm{a}}$ & 6.12 \\
& & -26.09 & $+2.64^{\mathrm{a}}$ & 6.22 \\
$583 \mathrm{~A}-3-4,38-39$ & 13.8 & -28.06 & +2.88 & 5.38 \\
$583 \mathrm{~A}-6-2,129-132$ & 26.8 & -29.24 & +2.23 & 7.68 \\
$583 \mathrm{C}-2-1,71-72$ & 30.7 & -31.42 & +2.54 & 6.57 \\
$583 \mathrm{C}-2-2,40-41$ & 31.9 & -28.48 & +2.27 & 7.54 \\
\hline
\end{tabular}

Note: $\delta^{13} \mathrm{C}$ and $\delta^{18} \mathrm{O}$ expressed in \%o versus PDB standard.

${ }^{a}$ Duplicate.

gregates may have been stabilized to some extent by the formation of methane hydrates (which are not at all uncommon at low seafloor temperatures and pressures of only a few hundred bars), their presence in Nankai Trough sediments suggests that this phase may in fact be much more widespread in the marine environment than has been previously supposed.

\section{ACKNOWLEDGMENTS}

We gratefully acknowledge the analytical help of M. Eatough, for the high-resolution X-ray work, and P. Hlava, for the microprobe analyses (both at Sandia National Laboratories). M. Goldhaber (United States Geological Survey) and I. R. Kaplan (University of California at Los Angeles) deserve special thanks for the isotope analyses. Discussions with M. Goldhaber and C. Yapp (University of New Mexico) contributed significantly to the synthesis of the data. Lastly, we are indebted to the other members of the scientific party of Leg $87 \mathrm{~A}$, the DSDP personnel, and the crew of the Glomar Challenger.

\section{REFERENCES}

Boggs, S., Jr., 1972. Petrography and geochemistry of rhombic calcite pseudomorphs from mid-Tertiary mudstones of the Pacific Northwest, U.S.A. Sedimentology, 19:219-235.
Chambers, W. F., 1979. BA78: an improved Bence-Albee analysis program for Tracor-Northern systems: Albuquerque, N. M. (Sandia National Laboratories), SAND78-1835.

Dana, E. S., 1984. A crystallographic study of the thinolite of Lake Lahontan. USGS Bull., 12:429-454.

Epstein, S., in press. The corrected oxygen isotope carbonate-water paleotemperature scale. Geochim. Cosmochim. Acta.

Kaplan, M. E., 1963. Calcite pseudomorphs (pseudogaylussite, jarrowite, thinolite, glendonite, gennoishi, White Sea hornlets) in sedimentary rocks. Origins of the pseudomorphs. In Urbakh, V. Y. (Ed.), Mathematical Statistics for Biologists and Physicians: Moscow (Izd. Akad. Nauk SSSR), pp. 623-636.

Katz, D. L., 1971. Depths to which frozen gas fields (gas hydrates) may be expected. J. Pet. Technol., 23(4):419-423.

Kemper, E., and Schmitz, H. H., 1975. Stellate nodules from the Upper Deer Bay Formation (Valanginian) of Arctic Canada. Geol. Surv. Pap. (Geol. Surv. Can.), Paper 75-1C:109-119. 1981. Glendonite-Indikatoren des polarmarinen Ablagerungsmilieus. Geol. Rundsch., 70:759.

Matsumoto, R., and Iijima, A., 1980. Carbonate diagenesis in cores from Sites 438 and 439 off northeast Honshu, northwest Pacific, Leg 57 Deep Sea Drilling Project. In Scientific Party, Init. Repts. DSDP, 57, 58, Pt. 2: Washington (U.S. Govt. Printing Office), $1117-1132$.

Moore, G. W., and Gieskes, J. M., 1980. Interaction between sediment and interstitial water near the Japan Trench, Leg 57, Deep Sea Drilling Project. In Scientific Party, Init. Repts. DSDP, 56, 57, Pt. 2: Washington (U.S. Govt. Printing Office), 1269-1276.

Pauly, H., 1963. Ikait, Nyt mineral der danner skaer. Nat. Verden, 1963:168-171.

Suess, E., Balzer, W., Hesse, K.-F., Müller, P. J., Ungerer, C. A., and Wefer, G., 1982. Calcium carbonate hexahydrate from organic-rich sediments of the Antarctic Shelf: precursors of glendonites. Science, 216:1128-1131.

Trechmann, C. O., 1901. Über einen Fund von ausgezeichneten Pseudogaylussit (=Thinolith= Jarrowit) Krystallen. Z. Krystallogr., 35(3):281-285.

Date of Initial Receipt: 9 January 1984

Date of Acceptance: 19 July 1984 

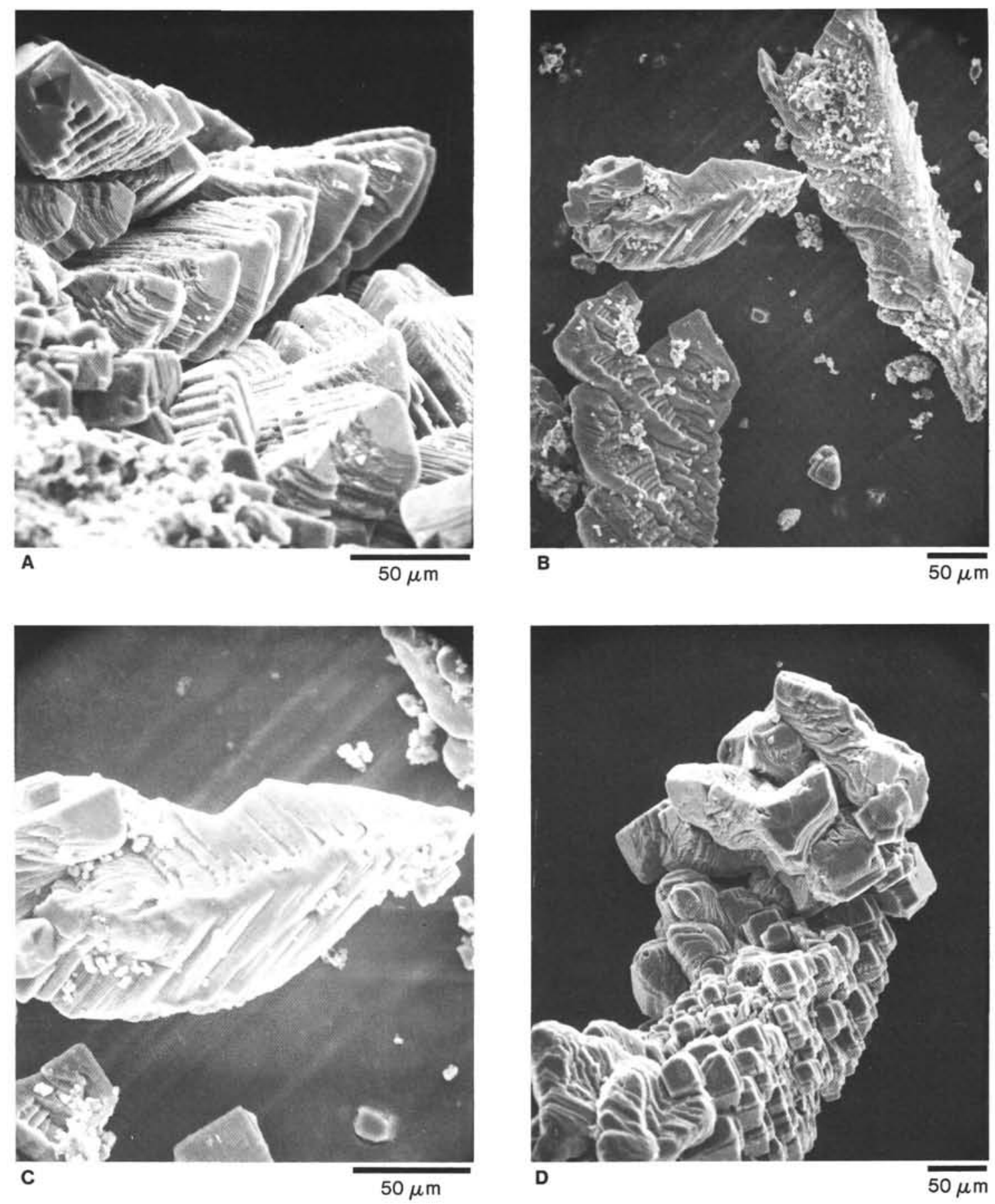

Figure 7. Scanning electron photomicrographs of carbonate fragments. A-C show what appear to be remnant scalenohedral forms similar to those reported in the early literature, although on a much smaller scale. D shows common rhombic texture, probably resulting from alteration of the original phase. 

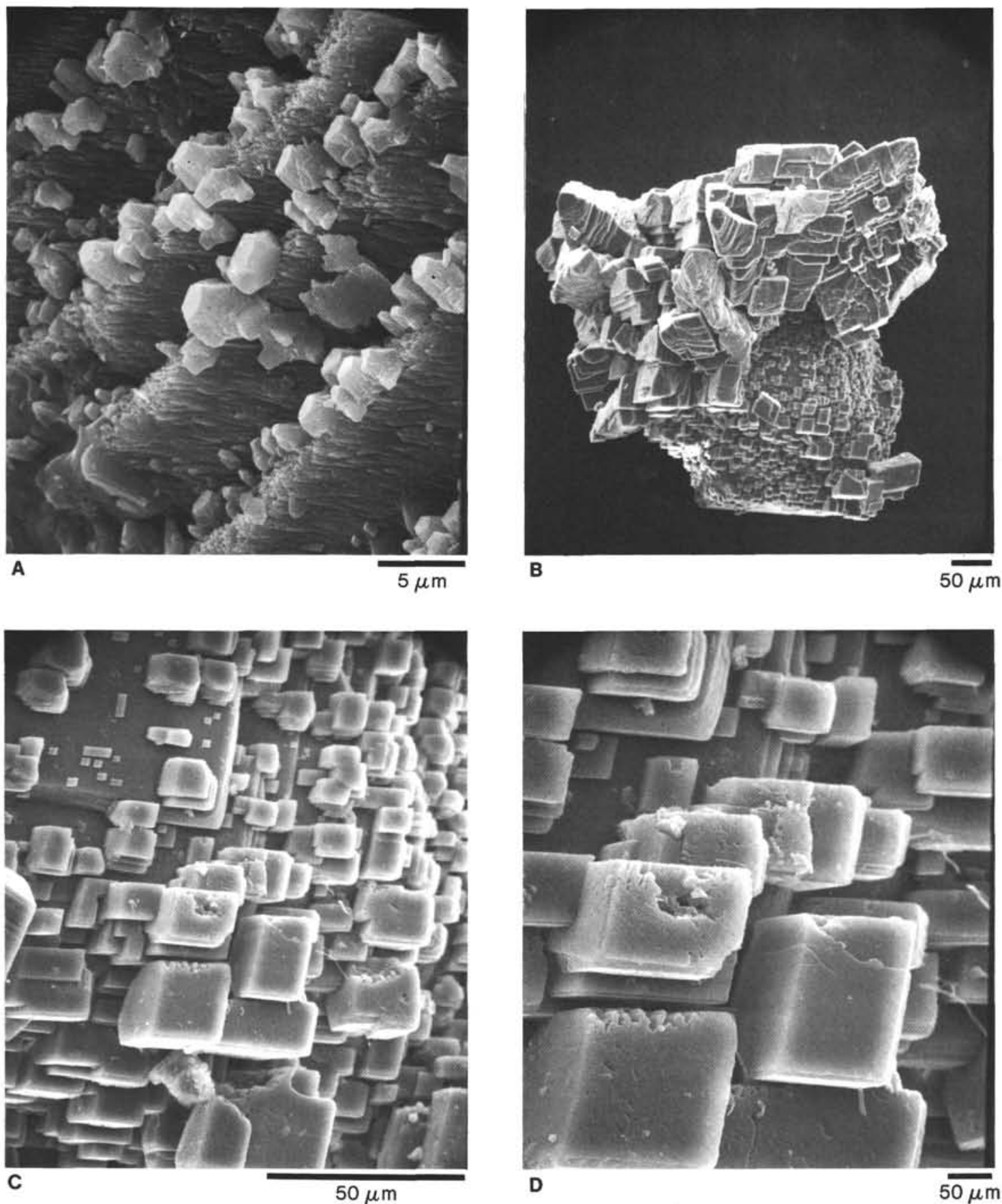

Figure 8. Rhombic crystal surfaces of carbonate fragments. A shows prismatic, fibrous form as described in Boggs (1972). B-D show more common rhombic forms. 


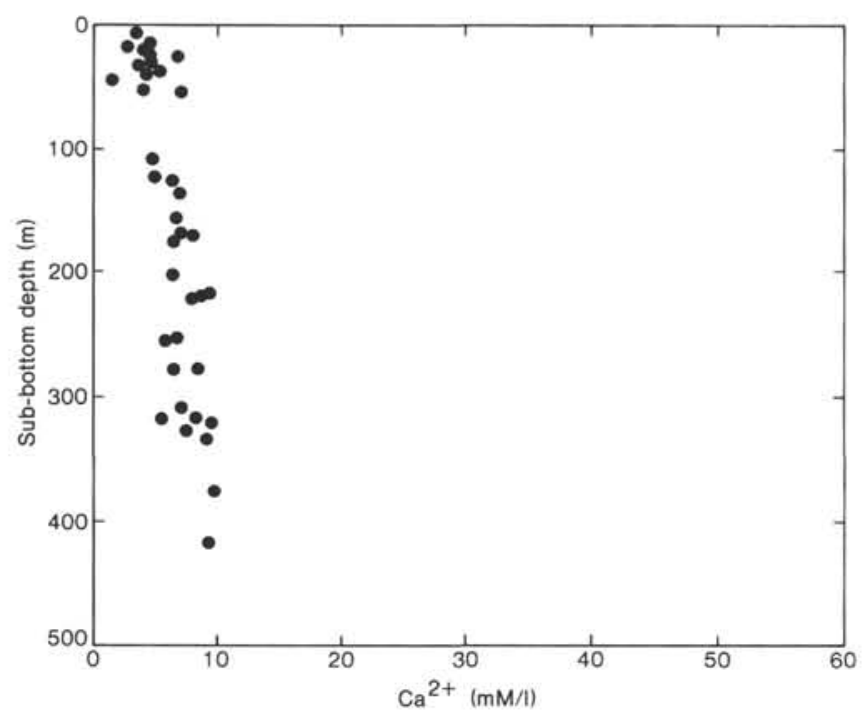

Figure 9. Pore water $\mathrm{Ca}^{2+}$ profile from Site 583.

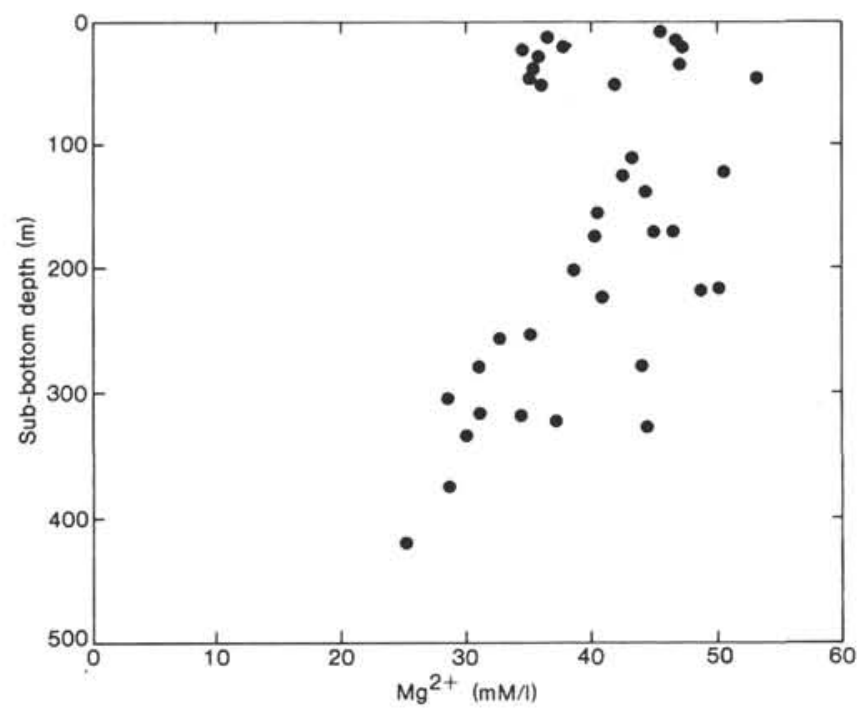

Figure 10. Pore water $\mathrm{Mg}^{2+}$ profile from Site 583 .

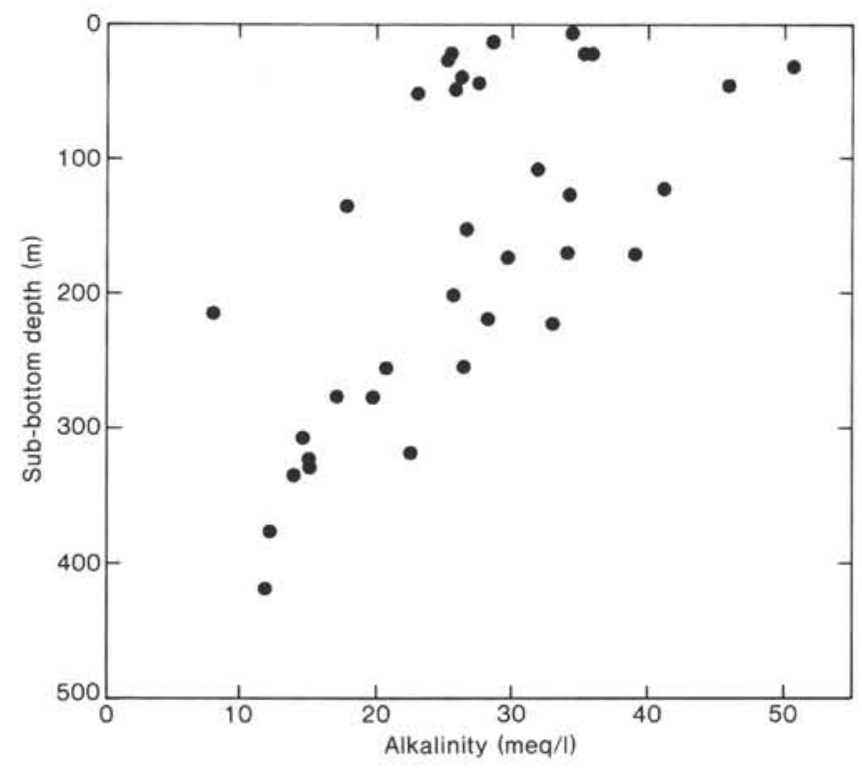

Figure 11. Pore water alkalinity profile from Site 583 . 